\title{
DOI 10.26886/2520-7474.5(37)2019.3
}

UDC: 336.711 .65

\section{THEORETICAL AND METHODOLOGICAL FOUNDATIONS OF MODERN BANKING SUPERVISION}

\author{
N. R. Shvets, Doctor of Economical Sciences, Professor \\ Chernivtsi University, Ukraine, Chernivtsi
}

The necessity of new, modern, adapted to the requirements of the economic realities theoretical and methodological bases of banking supervision implementation formation in Ukraine is justified by the author. The global and national trends in the functioning of the banking supervision system are investigated in the article. Some flaws and shortcomings in the action of international and national supervisory authorities are selected. The constructive proposals of the theoretical and methodological foundations of modern banking supervision in Ukraine are proposed.

Key words: bank, banking, banking supervision, the National Bank of Ukraine, the Basel Committee of Banking Supervision.

доктор економічних наук, профресор, Швець Н. Р. Теоретикометодологічні засади сучасного банківського нагляду / Чернівецький національний університет імені Юрія Федьковича, Україна, Чернівці

В представленій науковій статті автором обгрунтована необхідність формування нових, сучасних, адаптованих до вимог економічних реалій теоретико-методологічних засад здійснення банківського нагляду в Україні. У статmі досліджено світові та вітчизняні тенденції у функціонуванні системи нагляду за діяльністю банківських установ, виокремлено окремі недоліки та прорахунки у діяльності міжнародних і національних органів банківського нагляду та, на основі цього, сфрормовано конструктивні пропозиції з рефрормування теоретико-методологічних підвалин сучасного банківського нагляду 
України.

Ключові слова: банк, банківська діяльність, банківський нагляд, Національний банк України, Базельський комітет з питань банківського нагляду.

доктор экономических наук, профрессор, Швец Н. Р. Теоретикометодологические основы современного банковского надзора / Черновицкий национальный университет имени Юрия Федьковича, Украина, Черновцы

В представленной научной статье автором обоснована необходимость формирования новых, современных, адаптированных к требованиям экономических реалий теоретико-методологических основ осуществления банковского надзора в Украине. В статье исследованы мировые и отечественные тенденции в фрункционировании системы надзора за деятельностью банковских учреждений, выделены отдельные недостатки и просчеты $в$ деятельности международных и национальных органов банковского надзора $и$, на основе этого, сформированы конструктивные предложения по рефрормированию теоретико-методологических основ современного банковского надзора Украины.

Ключевые слова: банк, банковская деятельность, банковский надзор, Национальный банк Украины, Базельский комитет по банковскому надзору.

Вступ. Нові виклики сучасності ставлять перед системою банківського нагляду нові та складніші завдання, що потребують негайного вирішення. Особливо це стосується вітчизняної системи банківського нагляду, оскільки таких потрясінь, яких зазнала банківська система України в останні декілька місяців, вона, мабуть, не знала за всю новітню історію нашої держави. А тому існуючі теоретико- 
методологічні підвалини здійснення нагляду за діяльністю банківських установ в Україні вимагають масштабного перегляду та внесення відповідних корекцій і правок.

Формулювання мети статті та завдань. Саме поняття банківського нагляду у науковців завжди викликає широкі дискусії, оскільки ефективна система банківського нагляду повинна передбачати таку межу жорсткості, яка б дозволила банківським установам бути комерційно незалежними, але при цьому не загрожувала би нормальному розвитку економічних відносин в державі. Віднаходження цієї межі завжди і являється найскладнішим завданням, в основі якого i лежать власне фрундаментальні теоретикометодологічні засади формування та функціонування системи банківського нагляду в кожній окремо взятій державі. Зрозуміло, що зі зміною зовнішніх та внутрішніх чинників розвитку національної банківської системи буде змінюватися і національна система нагляду за діяльністю банківських установ. Але при цьому необхідно обов'язково пам'ятати про глобалізм банківської діяльності і враховувати це при формуванні власних правил здійснення банківського нагляду шляхом включення міжнародних стандартів, що розробляються на світовому рівні. Отже, основною метою даного наукового дослідження являється перегляд сучасних домінуючих теоретико-методичних засад здійснення банківського нагляду в Україні та світі й формування пропозицій щодо адаптації їх до сучасних викликів через виявлення недоліків і «вузьких місць» системи банківського нагляду України.

Виклад основного матеріалу статті. В результаті авторського дослідження теоретичних домінантів банківського нагляду виявлено, що ефрективність існування банків як фрінансових посередників пояснюється теорією фрінансового посередництва, що пройшла багато 
етапів своєї еволюції і відображена в дослідженнях багатьох науковців, серед яких можна виділити Дж. Герлі, Р. Голдсміта, Р. Левіна, А. Пігу, Дж. Штігліца, Й. Шумпетера. Згідно цих класичних досліджень необхідність і доцільність банківського нагляду та регулювання пояснюється ефектом довготривалих стосунків і теорією делегованого моніторингу, які визначають вимоги держави до мінімального розміру банківського капіталу та необхідність захищати інтереси вкладників і кредиторів банку. Саме ці функції і покликаний здійснювати банківський нагляд як підсистема державного регулювання банківської діяльності.

Окрім того, результатом аналізу понять і категорій зі ссрери банківського нагляду стало твердження, що терміни "банківське регулювання”, “банківський нагляд” і “банківський контроль” - це різні види діяльності державних органів банківського регулювання та нагляду щодо забезпечення стабільності й надійності функціонування банків, які $є$ взаємопов'язаними та взаємозалежними і доповнюють один одного 3 метою формування цілісної логічної системи державного нагляду та регулювання банківської системи. Хоча існують певні розбіжності в поглядах науковців на категорії «банківське регулювання» та «банківський нагляд» доцільно використовувати у дослідженнях законодавчо встановлені визначення даних понять.

Згідно чинного вітчизняного законодавства метою банківського нагляду в Україні $€$ забезпечення стабільності банківської системи та захист інтересів вкладників і кредиторів банку щодо безпеки зберігання коштів клієнтів на банківських рахунках. При цьому наглядова діяльність Національного банку України охоплює всі банки, їх відокремлені підрозділи, афрілійованих та споріднених осіб банків на території України та за кордоном, установи іноземних банків в Україні, а також інших юридичних та фрізичних осіб у частині дотримання вимог 
Закону України "Про банки і банківську діяльність" щодо здійснення банківської діяльності.

Під час здійснення банківського нагляду Національний банк України має право вимагати від банків та їх керівників усунення порушень банківського законодавства, виконання нормативноправових актів Національного банку України для уникнення або подолання небажаних наслідків, що можуть поставити під загрозу безпеку коштів, довірених таким банкам, або завдати шкоди належному веденню банківської діяльності.[1]

Необхідність посилення взаємозв'язку між наглядовими органами внаслідок поширення міжнародної фрінансової діяльності банків у деяких країнах Європи привела до створення єдиного державного наглядового органу (Управління з нагляду за сектором фрінансових послуг), що регулює та контролює діяльність різних фрінансових секторів (модель єдиного нагляду). В інших країнах, де також спостерігаються нові ринкові тенденції, розширені повноваження центральних банків у здійсненні наглядової діяльності та створені спеціальні структурні підрозділи, відповідальні за координацію взаємодії між різними наглядовими органами (секторна модель нагляду). У ряді країн використана модель «двох вершин», яка передбачає розподіл обов'язків з банківського нагляду між двома різними структурами в такий спосіб: один орган забезпечує відповідність фрінансових посередників установленим вимогам, а інший займається прозорістю ведення їх діяльності (модель нагляду за завданнями).

Результати аналізу досвіду побудови моделей наглядових систем у світі свідчать, що базовою моделлю для більшості країн $є$ секторна модель. Модель нагляду за завданнями, або модель «двох вершин», слід розглядати як перехідну від секторної до моделі єдиного нагляду. 
А перевагу єдиному регуляторному органу надають країни з високим і середнім рівнями концентрації фрінансового капіталу. Дані табл. 1 свідчать про надзвичайно високу концентрацію банківського капіталу в першій групі банків, а це 15 установ, банківської системи України, що обґрунтовує вибір нашою державою моделі єдиного регуляторного органу. Однак. достатньо швидкий розвиток ринку фрінансових послуг небанківських фрінансових установ переконує в тому, що питання вибору моделі нагляду за фрінансовими установами в Україні ще остаточно не закрите.

Таблиця 1

\section{Показники концентрації банківського капіталу в Україні}

на 01.10.2014p.*

\begin{tabular}{|c|c|c|c|}
\hline Група банків & $\begin{array}{r}\text { Частка } \\
\text { власного капіталу } \\
\text { в загальній сумі, \% }\end{array}$ & $\begin{array}{r}\text { Частка активів } \\
\text { у загальній сумі, \% }\end{array}$ & $\begin{array}{c}\text { Частка } \\
\text { зобов'язань в } \\
\text { загальній сумі, \% }\end{array}$ \\
\hline I (15 банків) & 66,1 & 69,8 & 70,3 \\
\hline II (17 банків) & 15,6 & 14,5 & 6,7 \\
\hline III (22 банки) & 4,3 & 6,4 & 8,6 \\
\hline IV (112 банків) & 14,0 & 9,3 & 14,4 \\
\hline
\end{tabular}

*Розраховано та складено автором за офріційними даними

Національного банку України

Процес досягнення цілей банківського нагляду сприяє виникненню та використанню різних регулятивних та наглядових тактик. В результаті проведених досліджень виділяємо нагляд за виконанням банками встановлених вимог (заснований на виконанні визначених правил) і ризик-орієнтований нагляд (базується на дотриманні певних принципів діяльності). Взаємодія між цими фрормами банківського нагляду зображена на рис. 1. 


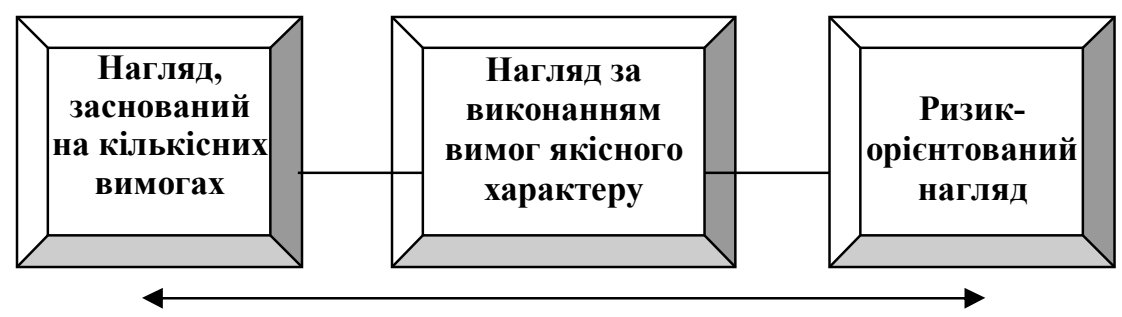

\section{Cтатичний підхід}

Перспективний підхід

Рис. 1. Динамічний аспект форм банківського нагляду

Переконані, що ефективною фрормою банківського нагляду, яка реалізує тактичні підходи, $€$ нагляд за дотриманням банками встановлених вимог, а основною фрормою реалізації стратегічних підходів - ризик-орієнтований нагляд.

Згідно з результатами власних досліджень - оптимальна для України така структура банківського нагляду, відповідно до якої частково делегуються фрункції контролю та нагляду визначеним учасникам фрінансового ринку, в процесі нагляду поєднуються правила та принципи зі значним переважанням правил у структурі нагляду. Окрім того, визначено, що в ході встановлення правил максимальний тягар нагляду за їх виконанням повинен лягати на банківські установи 3 нестійкими показниками діяльності.

Глобалізація фрінансових ринків висуває нові завдання у сфері взаємодії наглядових органів та обміну інформацією на міжнародному рівні, виконувати які необхідно, ґрунтуючись на взаємній довірі й розумінні з урахуванням конфріденційності. Тому стверджуємо про необхідність запровадження в українську банківську практику міжнародних стандартів Базельського комітету з питань банківського нагляду, зокрема Основних принципів ефективного банківського нагляду, які розглядаються як мінімальні вимоги, що повинні увійти до національних банківських законодавств країн.

Серед основних суперечностей та вимог сучасного розвитку 
банківського нагляду в Україні, які вимагають розробки вдосконалених теоретико-методологічних засад щодо його здійснення, визначаємо:

- відсутність в Україні практики консолідованого нагляду за фрінансовими групами;

- недостатній рівень публічності та розкриття узагальнюючої банківської інфрормації;

- зумовлена часом необхідність переходу від пруденційного до ризик-орієнтованого банківського нагляду;

- недосконала рання діагностика проблемності банків в Україні, що вимагає інтенсивного запровадження сучасних принципів превентивного банківського нагляду;

-недостатній рівень запровадження в Україні прогресивних механізмів та методик й інструментів банківського нагляду, проголошених Базелем II;

- необхідність розробки нового регулятивного механізму для банків, згідно з вимогами Базеля III.

В якості обґрунтування зазначених вище суперечностей та вимог пропонуємо наступні тези. Щодо першої і дуже важливої суперечності у сучасних тенденціях розвитку системи банківського нагляду в Україні, то хочемо зупинитися на таких особливостях консолідованого нагляду. Банкрутство низки великих міжнародних банків спонукало Базельський комітет з банківського нагляду встановити обов'язкові стандарти нагляду щодо міжнародних банківських груп у спеціальному документі, що носить назву «Базельський Конкордат» (Basel Concordat). У його основу покладено такі принципи:

- національні органи повинні здійснювати нагляд за міжнародними банками та міжнародними банківськими групами на консолідованій основі; 
- створення міжнародної банківської організації має отримати попередній дозвіл органів нагляду як країни походження, так і приймаючої країни;

- національні органи нагляду повинні володіти правом збору інфрормації про міжнародні банки і банківські групи, за якими вони спостерігають;

- якщо орган приймаючої країни визначає, що нагляд, здійснюваний у країні походження, не відповідає обов'язковим стандартам, він може заборонити міжнародні операції або накласти на них обмеження, відповідні його стандартам;

- органи нагляду країни походження повинні інформувати органи приймаючої країни про зміну заходів нагляду, що мають істотні наслідки для міжнародних операцій банку [2].

Завдання консолідованого нагляду полягає насамперед у тому, щоб не допустити втрати довіри і виникнення ланцюгової реакції, що виходить за рамки правової відповідальності. Оскільки умови і методи нагляду розрізняються залежно від правових, інституційних, історичних та інших факторів, не існує єдиного набору критеріїв, що дозволяють судити про ефрективність консолідованого нагляду. В принципі консолідований нагляд повинен враховувати і оцінювати всі ризики, які відчувають банківською групою, незалежно від місця їх локалізації, включаючи відділення та фрілії, небанківські компанії та афрілійовані фінансові установи.

Консолідований нагляд не повинен обмежуватися рамками консолідованого балансу і рахунків прибутків і збитків групи. Органи нагляду повинні враховувати особливу природу ризиків у даному випадку і виробляти належний підхід до них. Консолідований облік може бути навіть непридатним, коли характер ризиків різний, наприклад коли у кожного ринку свій ринковий ризик. Взаємозалік 
ринкового ризику в процесі консолідації рахунків може дати невірну позицію ризику потенційних збитків, особливо коли консолідація охоплює операції, що проводяться в країнах з невисоким рівнем контролю.[3; с.278-280]

На підставі визначених Законом України змісту здійснюваного в Україні банківського нагляду на консолідованій основі [4] і передбачених вимог до діяльності банківських груп (банківських підгруп) та з урахуванням досвіду країн і банківських систем, де вже діють положення такої форми нагляду [5; с.56], можна сформувати перелік економічних інструментів:

1. Встановлення вимог до розміру регулятивного капіталу банківської групи і його достатності на основі визначення нормативного капіталу групи 3 урахуванням особливостей вітчизняного законодавства.

2. Встановлення вимог до банківської групи (підгруп) щодо економічних нормативів, що обмежують концентрацію ризиків (кредитного, операційного, ринкового, ризику країни та ін.).

3. Впровадження системи лімітів та обмежень стосовно певних видів діяльності шляхом часткового обмеження чи заборони операцій банку з учасниками банківської групи та/або інсайдерами.

Щодо другої суперечності. Необхідно чітко розуміти, що прозора та якісна інформація має на меті передбачати й упереджувати негативні події, знижуючи таким чином імовірність їх виникнення. Недосконала рання діагностика проблемності банків, що вимагає інтенсивного запровадження сучасних принципів превентивного банківського нагляду, пов'язана насамперед з недостатнім рівнем розкриття узагальнюючої банківської інформації.

«Система раннього попередження», яка $€$ значним надбанням світового досвіду органів нагляду, базується на результатах аналізу 
звітності банків. Так, метою системи раннього попередження (СРП) є завчасне виявлення проблем в банку саме в найбільш ранні строки. А тому результативність СРП безпосередньо залежить від достовірності наданої банками звітності.

В Україні банки зобов'язані забезпечити проведення щорічної перевірки достовірності фрінансової звітності аудиторською фрірмою. Аудиторська перевірка банку здійснюється аудитором, який має сертифрікат НБУ на аудиторську перевірку банківських установ.

Основними причинами подання неякісної звітності можуть бути помилки й умисне приховування справжньої фрінансової ситуації в банку безпосередньо керівництвом. Таким чином, управлінський персонал банку намагається приховати негативні результати діяльності від акціонерів, клієнтів, органів банківського нагляду. Недостатній рівень розкриття та викривлення узагальненої банківської інфрормації унеможливлюють ранню діагностику проблемності банків, що вимагає розвитку механізмів контролю за банками щодо прозорості і якості подання фрінансової звітності, а також удосконалення практичних механізмів реалізації заходів впливу з боку наглядових органів до банків-порушників зазначених вище вимог.[6; с.127]

Щодо завчасної діагностики проблемності банків в Україні, хотілось би зазначити такі фракти. Національний банк України в 2014 році витратив на порятунок проблемних банків більше 13 мільярдів гривень. Банківський регулятор надав банкам, які згодом були визнані неплатоспроможними, кредити на термін понад 30 календарних днів на 13178 млн. гривень. За офріційною інформацією НБУ, серед банківодержувачів кредитів рефрінансування $€ 16$ банків, які згодом були визнані неплатоспроможними, і в даний час в них здійснюється тимчасова адміністрація або ліквідація.

В тому числі, найбільший обсяг коштів отримали банки: VAB Банк 
на 5535 млн. грн., Брокбізнесбанк - 2 млрд. грн., Всеукраїнський банк розвитку - 1473 млрд. грн., Укрбізнесбанк - 1029 млн. грн., Імексбанк - 795 млн. грн., Камбіо - 428 млн. грн. , Форум - 422 млн. грн., БГ Банк - 365 млн. грн., Актив-Банк - 342млн. грн., Єврогазбанк - 299 млн. грн., Південкомбанк - 180 млн. грн., Терра-Банк - 111млн. грн.

Окрім того, всього в 2014 році кредити НБУ отримали 75 банків на загальну суму 115613 млн. грн., однак з урахуванням повернення наданих кредитів на 189,43 млрд. грн. загальний обсяг заборгованості банків станом на 1 січня 2015 склав 108,95 млрд. грн. При цьому в 2014 році НБУ визнав неплатоспроможними 33 банки.[1]

Переконані, що приведена статистика свідчить про фрактичну відсутність превентивного нагляду в Україні.

Висновки. Отже, реформування теоретико-методологічних засад банківського нагляду України згідно зі сучасними викликами та стандартами міжнародної банківської практики, на наш погляд, передбачає такі основні положення:

- переорієнтація банківського нагляду на засоби превентивного контролю та раннє попередження проблем з врахуванням повного комплексу притаманних банкам ризиків;

- упровадження нагляду на консолідованій основі та запровадження відповідних інструментів консолідованого впливу на банківську групу з боку Національного банку України;

- підвищення вимог до рівня корпоративного управління в банках та банківських групах;

- посилення контролю за наявністю в банках та банківських групах положень, практик і процедур, спрямованих на протидію легалізації доходів, одержаних злочинним шляхом;

- підвищення якості аудиторських послуг і забезпечення належної взаємодії служби банківського нагляду й банківських аудиторів з метою 
забезпечення високої якості та прозорості банківської інформації;

- розширення обсягу та дієвості міжнародного співробітництва у сфрері банківського нагляду.

Здійснення банківського нагляду в Україні саме на таких теоретико-методологічних засадах дозволить забезпечити фінансову стійкість вітчизняної банківської системи та успішну ії інтеграцію до глобальних фрінансових ринків, уникаючи при цьому надмірного впливу спричинених цим процесом ризиків на банківську діяльність і забезпечуючи передумови для економічного зростання в державі.

\section{תimepamypa:}

1. Матеріали Національного банку України: [Електронний ресурс]. Режим доступу: http://www.bank.gov.ua/control/uk/index

2. Матеріали Базельського комітету з питань банківського нагляду: [Електронний ресурс]. - Режим доступу: http://www.bis.org/bcbs/

3. Грюнінг Х. ван, (2007). Аналіз банківських ризиків. Система оцінки корпоративного управління та управління фінансовим ризиком, Пер. 3 англ.; вступ, сл. д.е.н. К.Р. Тагірбекова, М., Всесвіт, 304 с.

4. Про внесення змін до деяких законів України щодо нагляду на консолідованій основі: Закон України від 19.05.2011 [Електронний ресурс] - Режим доступу: http://zakon1.rada.gov.ua/cgibin/laws/main.cgi?nreg=3394-17

5. Башлай С. (2011). Інструменти банківського нагляду на консолідованій основі., Фінансовий простір., №3., с. 54-59.

6. Бєлова І. (2013). Проблеми розкриття інфрормації у фрінансові звітності банків України., Актуальні проблеми економіки., №8., с. 123129.

References: 
1. Materialy Natsionalnoho banku Ukrainy: [Elektronnyi resurs]. - Rezhym dostupu: http://www.bank.gov.ua/control/uk/index

2. Materialy Bazelskoho komitetu z pytan bankivskoho nahliadu: [Elektronnyi resurs]. - Rezhym dostupu: http://www.bis.org/bcbs/

3. Hriuninh X. van, (2007). Analiz bankivskykh ryzykiv. Systema otsinky korporatyvnoho upravlinnia ta upravlinnia finansovym ryzykom, Per. z anhl.; vstup, sl. d.e.n. K.R. Tahirbekova, M., Vsesvit, 304 s.

4. Pro vnesennia zmin do deiakykh zakoniv Ukrainy shchodo nahliadu na konsolidovanii osnovi: Zakon Ukrainy vid 19.05.2011 [Elektronnyi resurs] Rezhym dostupu: http://zakon1.rada.gov.ua/cgibin/laws/main.cgi?nreg=3394-17

5. Bashlai S. (2011). Instrumenty bankivskoho nahliadu na konsolidovanii osnovi., Finansovyi prostir., №3., c. 54-59.

6. Bielova I. (2013). Problemy rozkryttia informatsii u finansovi zvitnosti bankiv Ukrainy., Aktualni problemy ekonomiky., №8., c. 123-129. 